\title{
Effect of drying methods on long term storage of hazelnut
}

\author{
Ali TURAN ${ }^{1} \mathbb{D}$, Hasan KARAOSMANOĞLU(D)
}

\begin{abstract}
This research was conducted to determine the chemical traits of Ordu Levant hazelnuts that were dried with sun-drying [on concrete ground (CG), grass ground (GG)], or in drying machine (DM) during 24 months of storage (2014-2016) at $20-25^{\circ} \mathrm{C}$ and $70-90 \%$ relative humidity. Drying process continued $39 \mathrm{~h}$ for CG and GG, and $23 \mathrm{~h}$ for DM. Sun-drying were performed in similar sunshine and environmental conditions. Nut quality traits in protein, lipid, moisture contents, water activity, free fatty acids (FFA), peroxide value (PV), rancimat value (RV), and amount of aflatoxin were investigated during storage. The lowest FFA $\left(0.35 \%\right.$, oleic acid) was recorded for GG, and the lowest PV $\left(0.35\right.$ meqO $\left.\mathrm{kg}^{-1}\right)$ was recorded for CG. In addition, DM method contained much more RV $(3.87 \mathrm{~h})$ than those dried by CG and GG. After 24 months of storage, kernel FFA (0.38\%, oleic acid) and RV $(3.59 \mathrm{~h})$ were lower than the acceptable limit values after storage $(0.40 \%$ and $3 \mathrm{~h}$, respectively). In conclusion, in-shell hazelnuts can be stored at an ambient temperature for 24 months without there being any significant changes in chemical traits. Overall, DM appears to be a promising strategy for hazelnut drying.
\end{abstract}

Keywords: aflatoxin; concrete ground; drying machine; free fatty acid; peroxide value; rancimat value.

Practical Application: Determination better drying method and change of chemical traits for period of 24 months storage

\section{Introduction}

Supplying the market with the best product available is always critical (Kaya et al., 2011). Proper harvest and post-harvest handling is key to achieving the maximum yield of good quality nuts, which determines their marketability and farmer profits (Kashaninejad et al., 2007). Hazelnut harvest and drying usually begins in early August and continues for about 6-8 weeks, depending on the maturity date of the cultivar, location, altitude and ecology in the Black Sea region of Turkey. Weather conditions are taken into consideration during hazelnut harvesting, since rain hinders harvest, and post-harvest proces, and drying becomes much more difficult (Ylldiz, 2016). The drying process is one of the oldest methods of agricultural products preservation (Turan, 2018a). In addition, drying is essential while processing postharvest hazelnuts inshells for ensuring food safety and quality during storage (Wang at al., 2018).

In Turkey, hazelnuts are traditionally dried in the sun on concrete ground (CG) and/or on grass ground (GG), which is labor-intensive, and drying time is prolonged under humid or rainy conditions (Turan, 2017). Drying is completed in two steps. First, the nuts in the husks are dried and the moisture content (MC) is reduced from $30-40 \%$ to $15-20 \%$ over about 5-10 days depending on the weather conditions. The husks are later removed by a husker machine (patoz), and the nuts are dried a second time during which $\mathrm{MC}$ is reduced to about $6 \%$. The total drying period takes about 15-30 days, depending on the weather conditions. If precipitation is high during the harvesting period, drying takes longer and the nuts deteriorate. Several extrinsic factors, such as humidity and temperature, can significantly affect hazelnut quality as well as the internal factors of kernel MC, since water activity influences nut quality (Ghirardello et al., 2013).

Hazelnuts are susceptible to rancidity due to their high unsatured fatty acid content, so they have to be dried immediately after harvest (Turan, 2019). A 3.5\%-5\% kernel MC ensures a long shelf-life and adds protection against the rancidification process (Richardson, 1988). It is important that the oil stability of kernels during the drying process and storage period is not affected (Turan \& İslam, 2016). Moreover, during drying process, food undergo rancidity and browning reactions which cause a spoilage of foods, because of odd colours and flavours formed (Lopez et al., 1997).

In Turkey, hazelnuts are conventionally harvested and sun-dried on the CG or GG and than stored at room temperature for a minimum of 12 months (Turan, 2017). If the market price is unstable, the storage period can exceed 12 months, and may even reach 24 months. Unfortunately, studies regarding the effect of the drying method [(CG, GG, or drying machine (DM)] and long-term storage (24 months) on the chemical properties of the Ordu Levant hazelnut are very limited (Turan \& İslam, 2018). Therefore, the objective of this study was to determine the effect of three drying methods, and long-term storage on the chemical properties of Levant hazelnuts grown in the Ordu province of Turkey. The results will contribute significantly to the separation of the former process (stored for at least 12 monhts) and from the new process (stored for $>12$ months), which is a 
major problem in the hazelnut trade. Moreover, the results will provide data comparable to those available in the literature.

\section{Materials and methods}

\subsection{Samples and drying methods}

The experiments were conducted on Levant quality hazelnuts harvested in a single orchard, in the Bayadi neighborhood (1 $40^{\circ} 54^{\prime} 06.99^{\prime} \mathrm{N}, 37^{\circ} 53^{\prime} 36.07^{\prime} \mathrm{E}, 300 \mathrm{~m}$ a.s.l) in the Altınordu district, of Ordu, Turkey in August 2014. Levant quality hazelnuts are composed of $44.5 \%$ Palaz, 34.0\% Tombul and 21.5\% Kalinkara cultivars. Nuts were harvested by hand by picking them up from the tree branches. The average kernel MC was about $25 \%$ at harvest (August 06 to August 10,2014). The clusters were spread on the GG and dehydrated for four days (August 11 to August 14, 2014) to allow moisture loss (22.04\%; Turan \& İslam, 2016). The nuts were separated from their husks using a husker (Dinçler Makine, FPHM 2500, Samsun, Turkey) and randomly divided into three groups: Group 1 was dried in the sun on GG. Grass was cut by a string trimmer (Oleo-Mac 440 T, Italy), canvas (TS 4739, TS 1534-2; EN ISO 2286-2, Kale Tente, İstanbul, Turkey) was laid on the ground, and the nut samples were placed on the canvas to dry in the sun with occasional mixing. In group 2, nuts were directly placed on CG (TS EN 12390, Gümüştaş Çimento, Giresun, Turkey) and dried in the sun with occasional mixing. The drying process continued $39 \mathrm{~h}$ for CG and GG (Table 1). It is mentioned that CG and GG methods were performed in similar sunshine and environmental conditions (average of wind velocity, ambient air temperature and relative humidity and sunshine duration; $1.4 \mathrm{~h} \mathrm{~km}^{-1}, 22.1{ }^{\circ} \mathrm{C}, 69.8 \%$ and $5.24 \mathrm{~h}$, respectively). The hazelnut on CG and GG methods were dried every day from 8:00 a.m. to 8:00 p.m. continuously. After 8:00 p.m., plastic cover (Metroplast, İstanbul, Turkey) was used to prevent the samples from getting wet. Group 3 was dried by placing them directly in a DM (FACMA ES 3000, 2013, Italy), which dried them with hot air at $45^{\circ} \mathrm{C}$ (Turan \& İslam, 2016). Namely, the desiccation was obtained by the forced ventilation of hot air, which the heat-exchanger sends to the ventilator, which at the same time pushes it inside the body of the dryer. The sample, continuously ventilated, was mixed by a central archimedean screw and it can be ventilated also with non heated air. The dryer adjusted in temperature was conditioned about $3 \mathrm{~h}$ each operation and $1.5 \mathrm{~h}$ cease. Meanwhile, the Archimedean screw has continued circulation for $1.5 \mathrm{~h}$ in every cycle. The drying process continued until the moisture content was up to $6.8 \%$ and lasted for $23 \mathrm{~h}$ (Table 1) and additionally, schematic diagram are detailed in Figure 1. Drying process were carried out 15 and $20^{\text {th }}$ day of August 2014 in the Karapınar neighborhood ( $140^{\circ} 58^{\prime} 17.53^{\prime \prime} \mathrm{N}$, $37^{\circ} 56^{\prime} 00.41^{\prime \prime} \mathrm{E}$, altitude $10 \mathrm{~m}$ ) in the Altınordu district, Ordu, Turkey (Ordu OSB, Gürsoy Tarımsal Ürünler Gıda Sanayi ve Ticaret A.Ş. Entegre Tesisi). The shell and kernel MC was measured before and after dehydration, and again after drying and before storage (Table 1). At the end of drying, the samples were stored under ambient temperature in jute bags $(10 \mathrm{~kg})$ and analyzed every three months (Faculty of Agriculture, Ordu University, Ordu, Turkey) and total of $90 \mathrm{~kg}$ nuts were used for the analysis.

\subsection{Storage conditions}

The dried nuts were stored in $10 \mathrm{~kg}$ jute bags in a store room under conditions of $20-25^{\circ} \mathrm{C}$ and $70-90 \%$ relative humidity (RH). The samples were stored for 24 months (2014-2016) and were analyzed every 12 weeks ( 3 months).

\subsection{Oil extraction}

The hazelnut oil was extracted through a cold press (Pressure force: $10000 \mathrm{kgf}$, pressure: $34.7 \mathrm{MPa}$, temperature: $-5^{\circ} \mathrm{C} \sim+45^{\circ} \mathrm{C}$ and capacity; $250 \mathrm{~g}$ kernel) method using that used the Ceselsan's nut oil extraction system (AISI3004, Ceselsan, Giresun, Turkey). Kernel samples of $\sim 3 \mathrm{~kg}$ kernel were randomly selected and compressed (Turan, 2017). The recovered oil was separated by centrifugation at $4800 \mathrm{rpm}$ for $5 \mathrm{~min}$ and the oil was stored at $-18{ }^{\circ} \mathrm{C}$ in freezer until analyzed.

\subsection{Protein and fat content}

Protein content $(\mathrm{PC})$ was determined using AOAC Standard Methods. PC $(\mathrm{N} \times 6.25)$ was estimated from $0.5 \mathrm{~g}$ samples by the macro Kjehldahl method (Velp UDK 149, Europe). Lipid

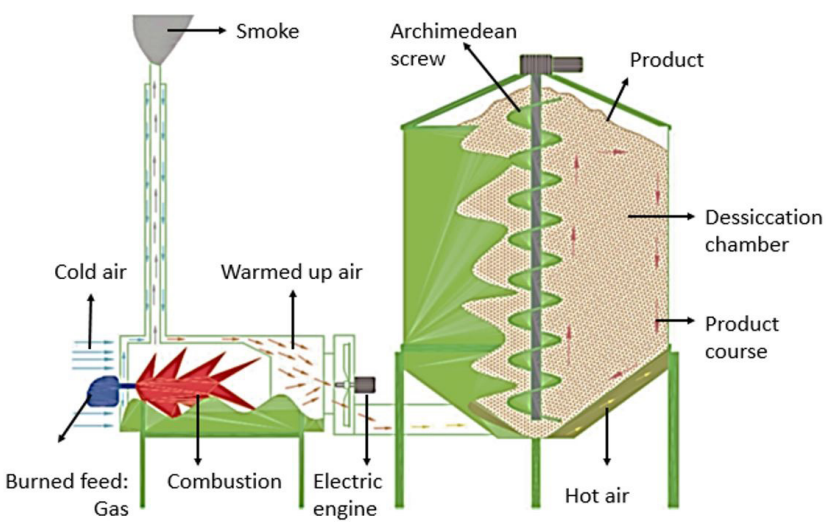

Figure 1. Schematic diagram of the dryer used for hazelnut drying.

Table 1. Moisture content of hazelnuts before and after dehydration, and after drying before storage and drying time.

\begin{tabular}{|c|c|c|c|c|c|c|c|}
\hline \multirow[t]{2}{*}{ Drying methods } & \multicolumn{2}{|c|}{ Initial moisture content (\%) } & \multicolumn{2}{|c|}{$\begin{array}{c}\text { Moisture content after dehydration } \\
(\%)\end{array}$} & \multicolumn{2}{|c|}{$\begin{array}{c}\text { Final moisture (\%) content, after } \\
\text { drying }\end{array}$} & \multirow[t]{2}{*}{ Drying time $(\mathrm{h})$} \\
\hline & Shell & Kernel & Shell & Kernel & Shell & Kernel & \\
\hline Concrete ground & & & & & 7.89 & 5.81 & 39 \\
\hline Grass ground & 27.25 & 25.36 & 24.48 & 22.04 & 9.11 & 6.10 & 39 \\
\hline Drying machine & & & & & 8.10 & 6.80 & 23 \\
\hline
\end{tabular}


content (LC) was determined according to AOAC Official Methods (Association of Official Analytical Chemists, 2000). LC was determined by extracting a known sample-weight (5 g) with petroleum ether, using a soxhlet apparatus (Velp Ser 148, Milano, Italy).

\subsection{Moisture content and water activity}

Moisture content (MC) was determined according to Turkish Standards Institution (TSE)-TS 3075/T1 standard (Turkish Standardization Institution, 2001). MC was evaluated on ground hazelnut (Fakir Motto 800w, Germany) samples in an oven (Refsan RK 55, Kütahya, Turkey) at $105^{\circ} \mathrm{C}$ until a constant weight was reached. Water activity $\left(\mathrm{a}_{\mathrm{w}}\right)$ was determined using the Novasina $\mathrm{a}_{\mathrm{w}}$ Sprint TH 500 (Switzerland; Water Activity Analyzer, 2004).

\subsection{Free fatty acids}

Free fatty acids (FFA) were determined by using the AOAC Standard Method (Association of Official Analytical Chemists, 1990a). A 2.5-5 g (m) samples of oil was weighed in a glass vial and dissolved in a 25-50 mL mixture of ethanol, diethyl ether $(1 / 1, \mathrm{v} / \mathrm{v})$, and $2-3$ drops of phenolphthalein. This was then titrated with $\mathrm{NaOH}(0.1 \mathrm{~N})(\mathrm{V})$ until the pink color persisted for at least 10s. FFA was calculated as FFA (\% oleic acid $)=(\mathrm{V} / \mathrm{m}) \times 28.2$.

\subsection{Peroxide and rancimat value}

To determine peroxide value (PV), 2-2.5 $\mathrm{g}$ of oil was weighed in a glass vial and dissolved in $100 \mathrm{~mL}$ acetic acid/isooctane $(3 / 2, v / v)$ and supplemented with $0.2 \mathrm{~mL}$ potassium iodide (Metrohm Dosimat 799, Switzerland; Association of Official Analytical Chemists, 1990b). The sample was then in a dark space for $5 \mathrm{~min}$, and $50 \mathrm{~mL}$ distilled water was then added. After titration, the value acquired was expressed as meqO $\mathrm{kg}^{-1}$. Ransimat value (RV) was determined by using a Ransimat 743 device (Metrohm, Switzerland; Velasco et al., 2004).

\subsection{Aflatoxins}

Total aflatoxin $(\mathrm{AF})$ and aflatoxin $\mathrm{B}_{1}\left(\mathrm{AFB}_{1}\right)$ were determined by high-performance lquid chromatography (Shumadzu, c2101390892100, RF: 10AXL, Japan; Turkish Standards Institution, 2010). Total $\mathrm{AF}$ and $\mathrm{AFB}_{1}$ were calculated as $\mathrm{ngg}^{-1}=50 \mathrm{~g} / 250 \mathrm{~mL} \times 5 \mathrm{~mL} / 2 \mathrm{~mL}$.

\subsection{Statistical analysis}

The experiments were performed in triplicates in a completely randomized block design. Descriptive statistics were obtained using SPSS v. 22.0 (Armok, New York: International Business Machines Corp.). Statistical tests were performed using SAS-JAMP v. 10.0 (SAS Institute Inc., Cary, North Carolina) and a one-way ANOVA was conducted to detect significant differences between the groups followed by least significance difference (LSD) for multiple mean comparisons. Results were considered significant at $p<0.05$.

\section{Results and discussion}

\subsection{Protein content}

Protein content $(\mathrm{PC})$ significantly increased $(p<0.001)$ during storage, but the increase was not constant (Table 2). These changes were related to the decrease or increase in MC. These results are in agreement with those Turan \& İslam (2016) and Koç Güler et al. (2017), who reported an increasing PC during storage. There was no significant difference in PC by drying method $(p>0.05)$. The same result trend was reported by Turan \& Islam (2016) and Kermani et al. (2017), who reported that drying methods had no significant effect on PC. However, Matin et al. (2013), who reported that the drying methods affect the PC and varied between cultivars.

\subsection{Lipid content}

Storage time, the total lipid content (LC) exhibited fluctuations and variability, but had slightly increased overall (Table 2; $p<0.001)$. These changes are likely due to partial hydration or rehydration in the kernel. This trend was in agreement with Turan \& İslam (2016), where LC significantly decreased during the storage period, but the decrease was not constant. By contrast, Ghirardello et al. (2013) reported that LC increased during storage while Koç Güler et al. (2017) reported that the oil content was nearly stable during storage. The drying methods significantly affected total LC $(p<0.01)$. The highest $\mathrm{LC}$ value was observed with DM (56.6\%), while the lowest value was observed with CG (54.7\%). However, Turan \& İslam (2016) and Kermani et al. (2017) reported that the drying method had no significant effect on LC. These differences could be due to such factors as farming and drying methods or genetic variation.

\subsection{Moisture content}

Moisture content (MC) of kernel never reached 5\%, which is the threshold value for the good preservation of hazelnuts (Turkish Standardization Institution, 2001). According to hazelnut purchase practices in Turkey, MC should be $\leq 6 \%$ (Fiskobirlik, 2004). The present results showed that MC decreased from $5.19 \%$ to $4.40 \%$ during storage (Table 2). This reduction was due to moisture loss in the kernel. The same result was reported by Turan \& İslam (2016), Koç Güler et al. (2017), and Turan (2017) kernel MC decreased during storage time.

\subsection{Water activity}

Water activity $\left(a_{w}\right)$ in food is one factor that affects the fat oxidation (Özdemir et al., 2002), and the oxidation rate was low at $\mathrm{a}_{\mathrm{w}}=0.3-0.5$; thus, a kernel $\mathrm{MC}<5 \%$ is desired. In the present study, water activity decreased from 0.72 to 0.40 during storage with fluctuations (Table 2). These results are in general compliance with the findings of Turan \& İslam (2016) and Koç Güler et al. (2017). It has been reported that AF may form if $a_{w}$ exceeds 0.83 over 2 days (Özay et al. 2008); therefore, kernel $a_{w}$ should never reach 0.83 . In the present study, water activity was below 0.72 ; the effect of drying methods on water activity was given Table 3. After 24 months of storage, a significantly higher water activity value was recorded for CG and DM $\left(a_{w}=0.63\right)$ 

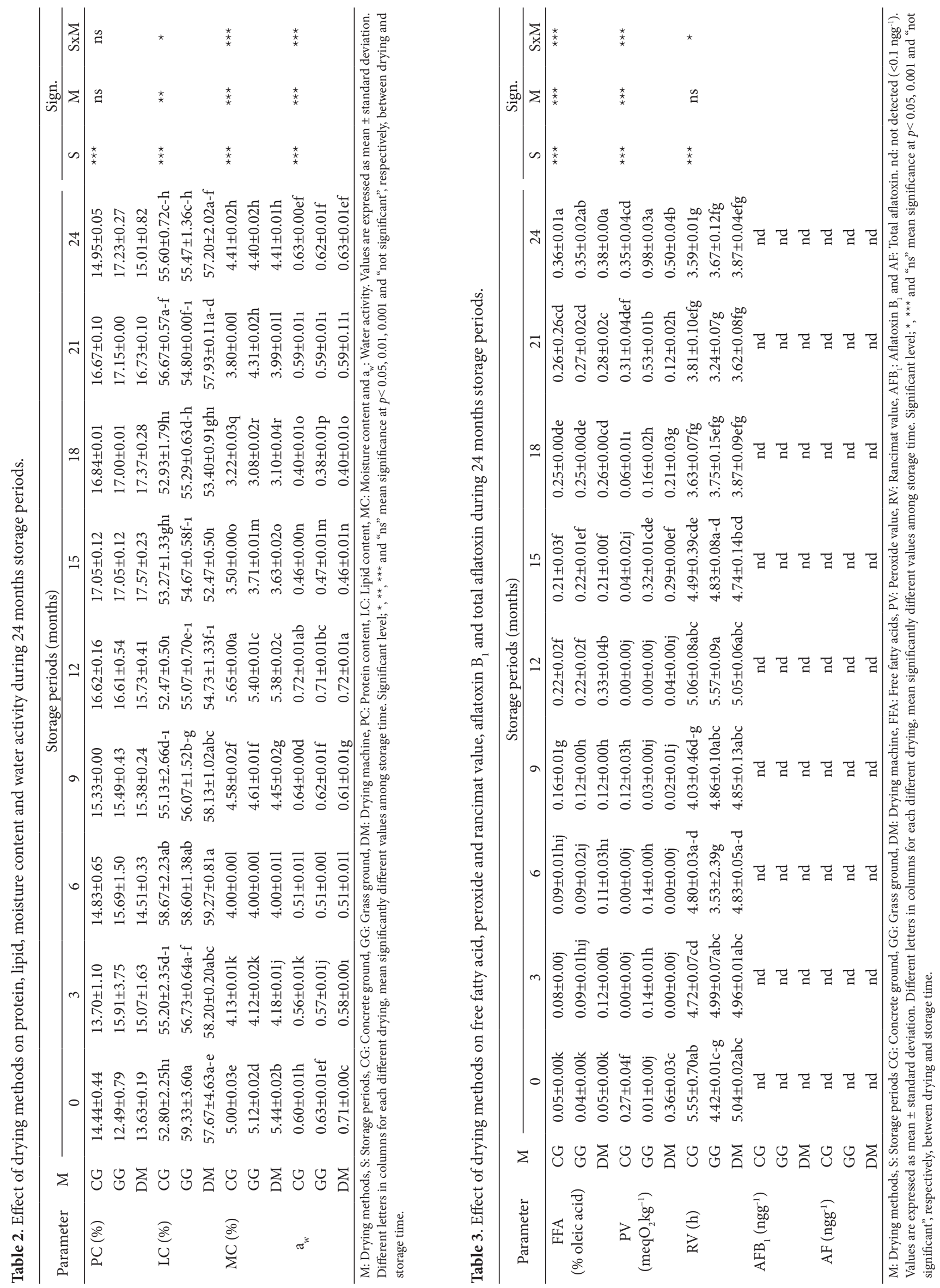
compared to GG $(0.62 ; p<0.001)$. These results are contrary to those reported by Turan \& İslam (2016), possibly due to differences in-shell and/or kernel characteristics of the cultivars and their water holding capacity.

\subsection{Free fatty acids}

Free fatty acid (FFA) is the first indication of quality loss, as lipid oxidation results in an undesirable taste caused by the oxidation of FFA (Fiskobirlik, 2004). FFA $\geq 1 \%$ indicates rancidity (Özdemir et al., 1998; Turan, 2019). In the present study, FFA increased from $0.04 \%$ to $0.36 \%$ during storage $(p<0.001$; Table 3). It has been reported by other researcher that the storage period significantly affected FFA content (Turan \& İslam, 2016; Koç Güler et al., 2017; Turan, 2018b; Karaosmanoğlu \& Üstün, 2019). Fu et al. (2016) and Qu et al. (2016) reported a higher FFA value for hazelnuts dried in the sun compared to those dried in a $\mathrm{DM}$. This difference was a result of prolonged drying time. Under the action of light, heat or lipase, FFA lipid molecules are released, and this can influence the stability of the oil (Fu et al., 2016; $\mathrm{Qu}$ et al, 2016). In addition, increasing temperature and relative humidity both have a synergistic effect on the lipolysis reaction and rate of FFA production (Tavakolipour et al., 2010). Thus, the rate of oil oxidation increased with a prolonged drying time and increased temperature. However, Kashaninejad et al. (2003) indicated that differences in FFA content were not significantly different among drying methods. During storage, FFA content increased for all drying methods. After 24 months of storage, FFA in-shell hazelnuts dried on CG, GG, or in a DM, were $0.36,0.35$ and $0.38 \%$ oleic acid, respectively. These values were lower than the acidity reported for superior extra-virgin olive oils $(0.40 \%$ oleic acid; the comparison was provided in the absence of indications for critical acidity values for the nut industry; Ghirardello et al., 2013). These values are the limit of acceptability after 24 months of storage.

\subsection{Peroxide value}

Peroxide value (PV) is one of parameter adopted by the nut industry to evaluate the storage aptitude of hazelnuts (Ghirardello et al., 2013; Turan, 2017; Koç Güler at al., 2017; Gadani et al., 2017). PV is also an important indicator of walnut oxidative rancidity, as it reflects the degree of lipid oxidation at the primary level (Fu et al., 2016). In our study, PV significantly increased during storage time $(p<0.001)$, but the increase was not constant (Table 3). PV increased to a maximum level during any storage time and then dropped (Demirci, 2009; Turan, 2017; Koç Güler et al., 2017; Belviso et al. 2017; Turan, 2018b; Turan, 2019). During the storage period, both peroxide formation and peroxide decomposition reactions occured at the same time; therefore, PV fluctuates. However, Evren (2011), Ghirardello et al. (2013), and Raisi et al. (2015) reported a continuous increase in PV during the storage period. Significant differences were observed among the drying methods during the storage period $(p<0.001)$. This result is in agreement with Qu et al. (2016) and Fu et al. (2016), who reported that PV of sun-dried walnuts increased steadily, reaching the highest value of 2.35 meqO $\mathrm{kg}^{-1}$ at the end of the drying period. In addition, $\mathrm{PV}$ of direct and intermittent oven-dried samples was 1.94 and $1.82 \mathrm{meqO}_{2} \mathrm{~kg}^{-1}$, respectively (Fu et al., 2016). It is clear that hazelnut samples exposed to long-term light and temperature had an increase in oil oxidation. Hence, it is critical that the drying process is carried out shortly after harvest for the long-term storage of hazelnuts.

\subsection{Rancimat value}

Rancimat value (RV) is based on the principle of water conductivity absorbing the degradation products formed as a result of peroxidation of unsaturated fatty acids in oils (Demirci, 2009). Polyunsaturated fatty acids are very important in oxidative degradation, which is low in varieties with low polyunsaturated fatty acids (Özdemir et al., 1998).

The interaction effect of drying and storage time was significant for RV ( $p<0.05$; Table 3 ). As expected, RV decreased with storage time for all drying methods. The results showed that RV decreased as oil oxidation increased, depending on the storage time and conditions. The present results are in general compliance with the findings of Lopez et al. (1995), Demirci (2009), Turan (2017), Turan (2018b), and Turan (2019), who reported decreasing RV during storage time. The highest RV was recorded for DM compared to CG AND GG (Table 3). This result is in agreement with Turan \& İslam (2016), where DM had a higher RV than drying on CG and GG. After 24 months of storage, hazelnut RV was higher (3.59-3.87 h) than the critical threshold value $(3 \mathrm{~h})$ reported that for oxidative stability in the Turkish nut industry. As such, $3 \mathrm{~h} \mathrm{RV}$ can be regarded as limit value at the end of 24 months of storage.

\subsection{Aflatoxin}

In Turkey, hazelnuts are traditionally sun-dried and may be subject to mold growth and, like other nuts, subsequent AF formation due to prolonged drying under humid and rainy conditions (Simşek et al., 2002). Thus, rapid drying and reducing $\mathrm{MC}$ in kernels is very important prevent fungal activity. Furthermore, fungal contamination and subsequent $\mathrm{AF}$ production can occur in hazelnuts in the orchard, at harvest, and during post-harvest operation (Özay et al., 2008). However, AF was not detected $\left(<0.1 \mathrm{ngg}^{-1}\right)$ in the present study although the storage conditions were appropriate for AF development. Thus, if AF was not detected during the mature hazelnut stage, they were not contaminated during the harvest, threshing, or storage period.

\section{Conclusion}

The present study investigated the effect of drying methods on the chemical properties of in-shell hazelnuts during storage. FFA increased during storage and never exceeded $0.38 \%$. $\mathrm{PV}$ increased in fluctuation during storage, and the highest values were recorded for GG. RV decreased during the storage period, and was lower for $\mathrm{DM}$ than for $\mathrm{CG}$ and GG. Total $\mathrm{AF}$ and $\mathrm{AFB}_{1}$ were not detected during the storage period. Therefore, when hazelnuts were stored in jute bags as in-shells at an ambient temperature, quality was maintained for a period of about 24 months. Consequently, DM was found to be more effective for the preservation of hazelnut quality than CG and GG. 


\section{Acknowledgements}

This study was supported by Gürsoy Tarımsal Urünler Gıda Sanayi ve Ticaret AŞ (Ordu, Turkey). The authors wishes to thank Dr. Fatih ÖNER for statistical analysis.

\section{References}

Association of Official Analytical Chemists - AOAC. (1990a). Official Methods and Recommended Practices of the American Oil Chemist's Society (5th ed). USA: American Oil Chemist Society.

Association of Official Analytical Chemists - AOAC. (1990b). Oils and Fats (pp. 485-518, 15th ed). Washington: Official Methods of Analysis of the Association of Official Analytical Chemists.

Association of Official Analytical Chemists - AOAC. (2000). Official Methods of Analysis of AOAC International (pp. 1-3, 17th ed). Arlington: AOAC.

Belviso, S., Dal Bello, B., Giacosa, S., Bertolino, M., Ghirardello, D., Giordano, M., Rolle, L., Gerbi, V., \& Zeppa, G. (2017). Chemical, mechanical and sensory monitoring of hot air and infrared roasted hazelnuts (Corylus avellana L.) during nine months of storage. Food Chemistry, 217, 398-408. http://dx.doi.org/10.1016/j. foodchem.2016.08.103. PMid:27664651.

Dermirci, E. T. (2009). Research on shelflife of processed hazelnut products (PhD Thesis). Ankara University, Ankara.

Evren, S. (2011). Storage stability of natural hazelnut flour. (PhD Thesis). 19 May University, Samsun.

Fiskobirlik. (2004). Fındık Alım-Ekspertiz, Saklama, Fındık Kırma, Fındık Kabuğu Satış Ve Dağıtımı, Tahvil, Tahliye, Hamaliye, Taşıma, Depo, Fabrika Ve Arsa Kiralama Yönetmeliği. Giresun: Fiskobirlik.

Fu, M., Qu, Q., Yang, X., \& Zhang, X. (2016). Effect of intermittent oven drying on lipid oxidation, fatty acids composition and antioxidant activities of walnut. Lebensmittel-Wissenschaft + Technologie, 65, 1126-1132. http://dx.doi.org/10.1016/j.lwt.2015.10.002.

Gadani, B. C., Mileski, K. M. C., Peixoto, L. S., \& Agostini, J. S. (2017). Physical and chemical characteristics of cashew nut flour stored and packaged with different packages. Food Science and Technology (Campinas), 37(4), 657-662. http://dx.doi.org/10.1590/1678-457x.27516.

Ghirardello, D., Contessa, C., Valentini, N., Zeppa, G., Rolle, R., Gerbi, V., \& Botta, R. (2013). Effect of storage condition on chemical and physical characteristics of hazelnut (Corylus avellana L.). Postharvest Biology and Technology, 81, 37-43. http://dx.doi.org/10.1016/j. postharvbio.2013.02.014.

Karaosmanoğlu, H. \& Üstün, N.Ş. (2019). Variation of fatty acid composition and oxidative stability of some hazelnut (Corylus avellana L.) varieties stored by traditional method. Grasas Aceites, 70(1), https://doi.org/10.3989/gya.0463181 In press.

Kashaninejad, M., Tabil, L. G., Mortazavi, A., \& Safeordi, A. (2003). Effect of drying methods on quality of pistachio nuts. Drying Technology, 21(5), 821-838. http://dx.doi.org/10.1081/DRT-120021688.

Kashaninejad, M., Mortazavi, A., Safekordi, A., \& Tabil, L. G. (2007). Thin-layer drying characteristics and modeling of pistachio nuts. Journal of Food Engineering, 78(1), 98-108. http://dx.doi.org/10.1016/j. jfoodeng.2005.09.007.

Kaya, A., Aydın, O., \& Akgün, M. (2011). Drying kinetics and moisture transfer parameters of hazelnut. Journal of Food Processing and Preservation, 35(5), 714-721. http://dx.doi.org/10.1111/j.17454549.2011.00522.x.

Kermani, A. M., Khashehchi, M., Kouravand, S., \& Sadeghi, A. (2017). Effect of intermittent microwave drying on quality characteristics of pistachio nuts. Drying Technology, 35(9), 1108-1116. http://dx.doi. org/10.1080/07373937.2016.1232270.

Koç Güler, S., Bostan, S. Z., \& Çon, A. H. (2017). Effects of gamma irradiation on chemical and sensory characteristics of natural hazelnut kernels. Postharvest Biology and Technology, 123, 12-21. http://dx.doi.org/10.1016/j.postharvbio.2016.08.007.

Lopez, A., Pique, M. T., Boatella, J., Parcerisa, J., Romero, A., Ferra, A., \& Garci, J. (1997). Influence of drying conditions on the hazelnut quality. I. Lipid oxidation. Drying Technology, 15, 3-4. http://dx.doi. org/10.101080/07373939708917271.

Lopez, A., Pique, M. T., Romero, A., \& Aleta, N. (1995). Influence of cold-storage conditions on the quality of unshelled walnuts. International Journal of Refrigeration, 18(8), 544-549. http://dx.doi. org/10.1016/0140-7007(96)81781-6.

Matin, A., Kricka, T., Jurisic, V., Bilandzija, N., Kuze, I., Voca, N., \& Landeka, M. (2013). Qualitative and energetic changes of hazelnuts after the process of convective drying. Krmiva, 1(55), 11-19.

Özay, G., Seyhan, F., Pembeci, C., Saklar, S., \& Yılmaz, A. (2008). Factors influencing fungal and aflatoxin levels in Turkish hazelnuts (Corylus avellana L.) during growth, harvest, drying and storage: A 3-year study. Food Addives Contaminants, 25: 209-218.

Özdemir, M., Ozay, G., \& Seyhan, F. G. (1998). Hasattan Ambalaja Fındik İşlemenin Kritik Kontrol Noktalarında Tehlike Analizi. GebzeKocaeli, Marmara Araştırma Merkezi.

Özdemir, M., Yıldız, M., \& Gürcan, T. Ş. (2002). Effect of artificial trying air temperature on stability of the major Turkish hazelnut variety Tombul. Gida, 27, 35-39.

Qu, Q., Yang, X., Fu, M., Chen, Q., Zhang, X., He, Z., \& Qiao, X. (2016). Effects of three conventional drying methods on the lipid oxidation, fatty acids composition, and antioxidant activities of walnut (Juglans regia L.). Drying Technology, 34(7), 822-829. http://dx.doi.org/10.1 080/07373937.2015.1081931.

Raisi, M., Ghorbani, M., Mahoonak, A. S., \& Kashaninejad, M. (2015). Effect of storage atmosphere and temperature on the oxidative stability of almond kernels during long term storage. Journal of Stored Products Research, 62, 16-21. http://dx.doi.org/10.1016/j. jspr.2015.03.004.

Richardson, D. G. (1988). Hazelnut quality. In Processing of the Annual Meeting of the Nut Growers Society of Oregon (pp. 83-86). Washington and British Columbia: Nut Growers Society of Oregon.

Simşek, O., Arici, M., \& Demir, C. (2002). Mycoflora of hazelnut (Corylus avellana L.) and aflatoxin content in hazelnut kernels artificially infected with Aspergillus paraticus. Die Nahrung, 46(3), 194-196. http://dx.doi.org/10.1002/1521-3803(20020501)46:3<194::AIDFOOD194>3.0.CO;2-D. PMid:12108220.

Tavakolipour, H., Armin, M., \& Kalbasi, A. A. (2010). Storage stability of Kerman pistachio nuts (Pistacia vera L.). International Journal of Food Engineering, 6(6), 1-11. http://dx.doi.org/10.2202/1556-3758.1740.

Turkish Standardization Institution - TSE. (2001). Hazelnut Kernels Standard. TS 3075. Turkey: TSE.

Turkish Standards Institution - TSE. (2010). Determination of aflatoxins in oil dried fruits. TSE, TS EN ISO 16050. Turkey: TSE.

Turan, A., \& Islam, A. (2016). Çakıldak fındık çeşidinde kurutma ortamları ve muhafaza süresine bağlı olarak meydana gelen değişimler. Ordu University Journal of Science and Technology, 6, 272-285.

Turan, A. (2017). Effect of drying methods on nut quality and storage of hazelnut. (PhD Thesis). Ordu University, Ordu.

Turan, A., \& Islam, A. (2018). Effect of drying methods on some chemical characteristics of hazelnuts (Corylus avellana L.) during storage. 
Journal of the Institute of Science and Technology, 8(3), 11-19. http:// dx.doi.org/10.21597/jist.458541.

Turan, A. (2018a). Effect of drying methods on nut quality of hazelnuts (Corylus avellana L.). Journal of Food Science and Technology, 55(11), 4554-4565. http://dx.doi.org/10.1007/s13197-018-3391-8. PMid:30333652.

Turan, A. (2018b). Effect of drying methods on fatty acid profiles and oil oxidation of hazelnut oil during storage. European Food Research and Technology, 244(12), 2181-2190. http://dx.doi.org/10.1007/ s00217-018-3128-y.

Turan, A. (2019). Effect of drying on storage conditions on the chemical composition of Çakıldak (cv) hazelnuts (Corylus avellana L.) during storage. Grasas Aceites, 70(1). https://doi.org/10.3989/gya.0693181 In press.

Velasco, J., Andersen, M. L., \& Skibsted, L. H. (2004). Evaluation of oxidative stability of vegetable oils by monitoring the tendency to radical formation. A comparison of electron spins resonance spectroscopy with the rancimat method and differential scanning calorimetry. Food Chemistry, 85(4), 623-632. http://dx.doi.org/10.1016/j. foodchem.2003.07.020.

Water Activity Aanalyzer - WAA. (2004). Operating Manual Novasina. AW Sprint TH 500 water activity analyzers. Switzerland:

Wang, W., Jung, J., McGorrin, R. J., Traber, M. G., Leonard, S. W., Cherian, G., \& Zhao, Y. (2018). Investigation of drying conditions on bioactive compounds, lipid oxidation, and enzyme activity of Oregon hazelnuts (Corylus avellana L.). Lebensmittel-Wissenschaft + Technologie, 90, 526-534. http://dx.doi.org/10.1016/j.lwt.2018.01.002.

Yıldiz, T. (2016). Labor requirements and work efficiencies of hazelnut harvesting using traditional and mechanical pick-up methods. Turkish Journal of Agriculture and Forestry, 40, 301-310. http:// dx.doi.org/10.3906/tar-1508-114. 